\title{
KOMUNIKASI NON VERBAL HOMOSEKSUAL (STUDI FENOMENOLOGI SIMBOL KOMUNIKASI KAUM GAY DI PEKANBARU)
}

\author{
Raja Widya Novchi \\ Fakultas Imu Komunikasi Universitas Muhammadiyah Riau \\ rayachi18@gmail.com \\ Khusnul Hanafi \\ Shally Isaura Zulietta \\ Universitas Muhammadiyah Riau \\ hanafie997@gmail.com
}

\begin{abstract}
Abstrak
Tujuan penelitian ini adalah untuk mengetahui simbol komunikasi yang digunakan oleh kaum gay di Pekanbaru dalam mencari pasangan. Penelitian ini menggunakan metode kualitatif dalam bentuk studi fenomenologi dengan melakukan observasi, dokumentasi dan wawancara mendalam terhadap subjek penelitian yang terdiri dari empat orang gay, satu orang teman gay, dan satu orang psikolog.Hasil penelitian menunjukkan bahwa kaum gay menggunakan komunikasi non verbal dalam mencari pasangan adalah sebagai berikut: pertama, simbol kontak mata ditandai dengan menatap pria lain secara lirik-lirikan beberapa kali dan menatap lebih lama ke arah pria yang menjadi target, biasanya lebih dari tiga detik dan dilakukan secara berulang-ulang. Kedua, simbol gerakan tubuh lebih terlihat pada gay yang berperan sebagai wanita, cara berjalan, gerakan tangan, pembawaan diriya yang gemulai bahkan dari cara memegang benda dapat terlihat dengan sangat jelas. Ketiga, simbol penampilan, jika gaya tipe top seperti pria metroseksual sedangkan bottom berpenampilan feminim. Keempat, simbol ekspresi wajah, yaitu menampilkan ekspresi wajah bahagia, senyum-senyum yang menggoda dan mengedipkan mata. Kesimpulannya menggunakan simbol ekpresi wajah, pada kaum gay sama seperti orang normal, ekspresi wajah akan disesuaikan dengan keadaan emosional pada saat melihat seseorang yang menjadi pusat perhatiannya.
\end{abstract}

Kata Kunci: Komunikasi non verbal, Gay, LGBT, Fenomenologi.

\begin{abstract}
The purpose of this study was to find out the communication symbols used by gays in Pekanbaru in finding partners. This study uses qualitative methods in the form of phenomenological studies by conducting observations, documentation and in-depth interviews with research subjects consisting of four gay people, one gay friend, and one psychologist. The results showed that gays used non-verbal communication in finding partners as follows: first, the symbol of eye contact was marked by staring at another man lyrically a few times and staring longer at the target man, usually more than three seconds and done repeatedly. Second, the symbol of body movement is more visible in gays who act as women, how to walk, hand movements, graceful disposition even from how to hold objects can be seen very clearly. Third, the symbol of appearance, if the top type style is like a metrosexual man while the bottom is feminine. Fourth, a symbol of facial expression, which is a happy facial expression, seductive smiles and a wink. The conclusion is using the symbol of facial expression, in gays as well as normal people, facial expressions will be adjusted to the emotional state when seeing someone who is the center of attention.
\end{abstract}

Keywords: Non verbal communication, Gay, LGBT, Phenomenology.

(C) 2018 Universitas Muria Kudus 


\section{PENDAHULUAN}

Menurut Oetomo (Corytawaty \& Lobodally, 2018) homoseksual mengacu pada perasaan tertarik baik secara perasaan (hubungan emosional maupun kasih sayang) maupun secara erotis yaitu secara predominan (menonjol) atau eksklusif (semata-mata) kepada sesama jenis kelamin dengan atau tanpa melalui hubungan fisik. Aktivitas homoseksual pertama dalam sejarah dapat ditelusuri diberbagai kitab suci, baik agama Kristen maupun agama Islam. Dalam agama Islam yaitu kitab suci Al-qur;an telah dijelaskan bahwa perilaku homoseksual pertama kali dilakukan oleh kaum Sadum. Sedangkan negara pertama kali yang melegalkan pernikahan sesama jenis adalah negara Belanda tahun 1996 (Belinda Kaya 2016, 2).

Allah berfirman dalam Surat Al-A'raaf (7) ayat 80-81 bahwa kaum Sadum (Sodom) telah melakukan perbuatan haram fahisyah, yang belum pernah manusia melakukannya. Ibnu Katsir dalam tasirnya menjelaskan bahwa fahisyah adalah laki-laki menggauli laki-laki lainnya dan bukan wanita, padahal Allah sudah menciptakan mahluk hidup berpasang-pasangan (Musti'ah 2016, 259). Banyak alasan yang menyebabkan seorang laki-laki menjadi gay, bisa karena alasan biologis, psikologis maupun lingkungan. Kecenderungan menyukai sesama jenis dapat dirasakan sejak remaja maupun telah dewasa (Lestari 2012, 4). Kampanye global untuk mendukung LGBT sudah terbetuk 40 tahun yang lalu pada akhir dekade 70-an. Momentum yang menandai gerakan global untuk mendukung sekaligus memperjuangkan status dan hak-hak LGBT, salah satunya adalah mendukung hak kaum gay (Cooper, 2006). Di Indonesia, pelaku LGBT khususnya kaum gay memiliki organisasi, salah satunya adalah organisasi Gaya Nusantara (Suherry dkk, 2016).

Dalam buku penelitian sosiologi yang ditulis oleh Siahaan (2009) menyebutkan salah satu tujuan dari pendirian organisasi LGBT adalah untuk memperjuangkan hak-hak kaum minoritas seperti waria, lesbian, biseksual, gay, dan transgender dalam hal untuk melegalisasi kebiasaan dan hukum. Di Kota Pekanbaru sangat mudah menemukan komunitas gay, salah satunya cara untuk mengetahuinya adalah dengan melihat akun facebook Gay Pekanbaru. Pada bulan Juni ini, komunitas gay Pekanbaru di media sosial facebook memiliki anggota sebanyak 3359. Dalam akun facebook ini mereka saling bertukar informasi yang berkaitan dengan orientasi seksualitas, bahkan terkadang mencari pasangan. Tidak hanya itu saja, mereka juga sering membuat jadwal untuk bertemu dengan anggota gay lainnya tetapi tempat yang dijadwalkan tidak selalu sama, tergantung kesepakatan antar anggota gay saja. Mereka mengatur jadwal pertemuan dan tempat yang berbeda untuk menghindari pandangan masyarakat yang sangat tidak nyaman berada diantara komunitas gay apabila berada di tempat umum. 
Dengan adanya simbol-simbol mereka dapat meluahkan hasrat, perasaan, pikiran, mengerti dengan makna simbol (Agustine, 2005). Salah satu bentuk komunikasi non verbal seperti tatapan, cara berpakaian, ekspresi wajah, gerakan tangan dan kode-kode tertentu hanya mereka saja yang dapat memahaminya. Berdasarkan fenomena diatas, peneliti sangat tertarik untuk mengetahui dan mendalami aktivitas gay dari segi berkomunikasi yang dilakukan secara sembunyi-sembunyi antar sesamanya.

\section{METODE PENELITIAN}

Metode penelitian adalah cara atau langkah-langkah untuk memperoleh pengetahuan ilmiah (Suryana, 2010). Dalam penelitian ini, penulis menggunakan metode kualitatif, dengan pendekatan fenomenologi dan menggunakan aspek aksiologis. Periantalo (2016) mengartikan metodelogi kualitatif adalah prosedur penelitian dengan sudut pandang induktif dengan tujuan untuk melihat keadaan subjek secara mendalam yang dilakukan dengan observasi, wawancara dan rekaman pada subjek yang jumlahnya sedikit. Metode kualitatif digunakan karena dianggap mampu melihat lebih dalam bagaimana fenomena gay di Pekanbaru. Sedangkan teknik pengumpulan data melalui wawancara mendalam dengan subjek. Tujuan dilakukan teknik wawancara mendalam adalah untuk menggali lebih dalam informasi dari informan atau narasumber yang diteliti oleh penulis. Kelengkapan data lainnya penulis peroleh dengan teknik observasi dan dokumentasi melaui dokumen-dokumen admnistratif, kliping, foto dan video di media massa, situs gay, artikel-artikel dan jurnal hasil penelitian yang berhubungan dengan gay. Pengumpulan data pada kajian ini menggunakan teknik purposive sampling. Tujuannya adalah untuk mempermudah penulis dalam memilih siapa saja yang akan diwawancarai dan ini hsesuai dengan tema yang diangkat oleh penulis. Subjek kajian adalah kaum gay, teman gay, dan psikolog di Pekanbaru. Sedangkan untuk Iokasi, penulis memlilih kota Pekanbaru karena Pekanbaru merupakan ibu kota dari Provonsi Riau dan dikenal dengan nuansa melayu dan religiusnya, apabila ini diabaikan maka fenomena ini akan semakin menyebar dan banyak generasi muda yang terkena dampak dari kaum gay tersebut.

Tabel 1. Subjek Penelitian

\begin{tabular}{lllll}
\hline No & \multicolumn{1}{c}{ Nama } & \multicolumn{1}{c}{ Umur } & \multicolumn{1}{c}{ Pekerjaan } & \multicolumn{1}{c}{ Keterangan } \\
\hline 1 & Joy & 26 Tahun & Swasta & Gay top \\
\hline 2 & Udin & 25 Tahun & Swasta & Gay \\
\hline 3 & Raka & 23 Tahun & Swasta & Gay \\
\hline 4 & Doni & 24 Tahun & Swasta & Gay bottom \\
\hline
\end{tabular}




\begin{tabular}{lllll}
\hline 5 & Triana & 24 Tahun & Swasta & $\begin{array}{l}\text { Masyarakat } \\
\text { Umum/ Teman } \\
\text { Gay }\end{array}$ \\
\hline 6 & Puti & 30 Tahun & Psikolog & Psikolog \\
\hline
\end{tabular}

\section{HASIL \& PEMBAHASAN}

Keberadaan gay di masyarakat Pekanbaru sangat dilarang oleh masyarakat Pekanbaru, hal ini membuat kaum gay sangat sulit mencari pasangan secara terbuka. Adanya faktor penghambat yang dirasakan oleh gay di Pekanbaru membuat mereka menggunakan media sosial. Salah satu media sosial facebook sangat populer bagi kaum gay karena mereka dengan mudah mencari informasi yang berkaitan dengan hasrat seksualitasnya. Dengan adanya media yang digunakan semakin mempermudah kaum gay untuk menggunakan pesan-pesan non verbal yang esensinya hanya diketahui oleh sesama mereka. Untuk dapat menelisik lebih dalam tentang komunikasi non verbal yang mereka gunakan penulis melakukan wawancara mendalam dengan empat orang narasumber yaitu anggota dari komunitas gay Pekanbaru. Ketika observasi berlangsung penulis menemukan narasumber yang sudah terbuka kepada masyarakat tentang orientasi seskualitasnya. Penulis juga mendapatkan informan yang sulit terbuka dengan orientasi seksualitasnya disebabkan adanya privasi diri dan takut berdampak negatif terhadap dirinya apabila ia terlalu membuka statusnya sebagai seorang gay.

Data yang penulis dapatkan dilapangan melalui hasil wawancara mendalam, observasi dan dokumentasi mengenai simbol-simbol komunikasi non verbal yang digunakan oleh kaum gay antara lain adalah:

1. Simbol Kontak Mata, dari hasil observasi dan wawancara medalam, informan menyebutkan kontak mata merupakan hal yang paling penting dalam menarik perhatian calon pasangan atau target. Hasil petikan wawancara dengan informan Joy:

"Kalau saya, simbol yang pastinya digunakan dalam melihat orang itu tertarik dengan kita adalah melaui kontak mata. Tidak ada cowok normal yang mau pandang-pandangan sesama cowok. Nah, dari itu saya bisa tau dan menilai mana cowok normal dan yang belok" (Wawancara mendalam dengan Joy, 9 Desember 2017).

Menurut informan Joy bahwa kontak mata memiliki peranan yang penting untuk mengetahui laki-laki tersebut normal atau gay. Menurut Joy, dengan adanya simbol kontak mata yang diberikan oleh gay lainnya mereka dapat saling mengenali mana laki-laki normal dan tidak normal. Dengan adanya kontak mata, gay langsung mendapatkan feedback dari proses komunikasi non verbal.

2. Simbol Gerakan Tubuh, sebagai salah satu saluran dari komunikasi non verbal, gerakan tubuh memberikan tanda non verbal sehngga kita bisa mengetahui keadaan 
emosional seseorang. Dalam mencari psangan, gay memperhatikan gerakan tubuh target karena laki-laki gay memiliki bahasa tubuh yang khas dibandingkan dengan laki-laki normal.

“Kalau gerakan tubuh gay bottom biasanya gerakan melambai seperti penari Jawa, menebarkan senyuman ceria, menggambarkan wanita yang lembut dan lemah gemulai.Untuk tipe gay top, badannya tegap seperti cowok nirmal tapi ketika jalan tetap keliatan juga bedanya (Wawancara mendalam dengan Raka, 16 Desember 2017).

Menurut informan Raka, simbol gerakan tubuh gay dapat diketahui dari gerakan tubuhnya. Dari pernyataan infoman dapat diperoleh infomasi bahwa gay yang bottom lebih kemayu seperti wanita dan gay tipe top mempunyai badan yang tegap, tetapi ketika berjalan tetap berbeda dengan laki-laki normal.

3. Simbol penampilan, gay yang ingin menarik perhatian dari calon pasangan harus berpenampilan rapi dan modis. Umumnya laki-laki gay sangat memperhatikan penampilan dan berdandan serapi mungkin.

"kalau dari cara berpakaian gay top biasanya sih memakai warna yang ngejreng dan pakaian ketat yang menampakkan lekuk badan, rajin perawatan, pakai handbag. Untuk gay yang bottom rambutnya diwarnai, kuku menipedi, pakai stiker-stiker, parfum yang jarak 20 meter masih kecium baunya (Wawancara mendalam dengan Udin, 3 Januari 2018).

Hasil wawancara mendalam dengan informan Udin menyatakan bahwa gay top cenderung menunjukkan bentuk dan lekuk badan menggunakan pakaian ketat dan menggunakan handbag seperti laki-laki metroseskual. Sedangkan untuk gaybottom berpenampilan seperti wanita seperti menggunakan make up dan aksesoris.

4. Simbol Ekspresi Wajah, salah satu bentuk dari komuniaksi nonverbal adalah ekspresi wajah karena wajah adalah alat yang sangat penting dalam menyampaikan makna.

“Kalau ekspresi wajah teman saya yang gay cari pasangan, hampir sama seperti kita perempuan. Kalau ada cowo ganteng yang kita suka maka kita akan menunjukkan ekspresi wajah ceria, senyuman manis dan ekspresi kita yang paling cantik. Kalau tidak suka, kita pasang muka datar atau memalingkan wajah (Wawancara dengan Triana, 2 Januari 2018).

Berdasarkan hasil wawancara dengan teman gay Triana, dalam menggunakan simbol ekpresi wajah, pada kaum gay sama seperti orang normal, ekspresi wajah akan disesuaikan dengan keadaan emosional pada saat melihat seseorang yang menjadi pusat perhatiannya.

\section{SIMPULAN}

\section{Kesimpulan}

Simbol komunikasi non verbal yang dilakukan oleh kaum gay di Pekanbaru adalah sebagai berikut: 
1. Simbol kontak mata, dalam mencari pasangan kaum gay berkomunikasi menggunakan kontak mata dengan menatap laki-laki lain seperti lirik-lirikan, curi pandang beberapa kali dan menatap lebih lama ke arah laki-laki yang menjadi targetnya. Jika laki-laki yang diberikan simbol kontak mata merespon dengan saling menatap dan tersenyum maka dapat dikatakan bahwa pria tersebut juga gay.

2. Simbol gerakan tubuh, pada simbol ini gay tipe bottom berperilaku seperti wanita, mulai dari cara berjalan, gerakan tangan, lemah gemulai dan memegang benda. Sedangkan pada gay tipe top walaupun memiliki tubuh tegap tetap terlihat ketika berjalan.

3. Simbol penampilan, pada gay tipe bottom berpenampilan seperti wanita seperti pemilihan baju dan aksesoris. Untuk gay tipe top berpenampilan lebih modis, matching, menggunakan handbag dan update merek terkenal, menggunakan pakaian warna cerah, ketat dan suka menampakkan lekuk tubuh.

4. Simbol ekspresi wajah, pada kaum simbol gay ekpresi wajah pada saat menyukai seseorang sama dengan orang normal. Apabila ia tertarik dengan calon pasangannya ia akan menampilkan ekpresi wajah bahagia, senyuman yang menggoda dan terkadang mengedipkan mata.

Jadi, simbol ekpresi wajah, pada kaum gay sama seperti orang normal, ekspresi wajah akan disesuaikan dengan keadaan emosional pada saat melihat seseorang yang menjadi pusat perhatiannya.

\section{Saran}

1. Ormas anti LGBT harus bersedia mengerahkan tenaga lebih untuk memberikan penyuluhan-penyuluhan berkaitan dengan LGBT.

2. Para psikolog dan psikiater harus mempunyai satu tujuan untuk membantu pelaku-pelaku gay untuk kembali menjadi manusia normal.

3. Masyarakat umum harus turut serta membantu mendukung pemerintah, ormas, psikolog dan psikiater dalam mencegah dan memberantas LGBT sehingga pergerakan LGBT tidak semakin meluas.

4. Orang tua harus mendidik anak dengan pendidikan agama, pendidikan seks, memilih teman bermain, dan memilih tontonan sedari anak masih kecil.

5. Mengajak kaum LGBT mengikuti kegitan bermanfaat seperti turut serta dalam kegiatan komunitas positif dan pengajian keagamaan.

6. Sebaiknya masyarakat tidak mengucilkan kaum gay karena hal ini tidak akan bisa menyelesaikan masalah. Mereka perlu dirangkul sehingga akan lebih mudah nantinya mereka menerima nasehat dari orang yang peduli padanya. 


\section{DAFTAR PUSTAKA}

Abdullah (1994). Tafsir Ibnu Katsir Jilid 1 dan 5. Terjemahan M. Abdul Ghoffar, Abdurrohim Mu'thi, Abu Ihsan Al- Atsari. Bogo: Pustaka Imam Syafi'i.

Adler, R., Rosenfeld, L. Proctor R \& Winder (2009). Interplay: The Process of Interpersonal Communication. Don Millls. Ontario: Oxpord University Press.

Agustine (2005). All About Lesbian. Jakarta: Ardhanary Institute

Atwater, E \& Duffy, K.G (2005). Phsycology for Living: Adjusment, Growth and Behaviour Today. Newas Jersey: Pearson Prentice.

Baumle, A. K (2010). Border Identities. Intersection of Ethnicity and Sexual Orientation in the U.S. Mexico Borderland. Social Science Research. Vol. 39: 231-245.

Belinda Kaya (2016).Representasi Homoseksual dalam Film the Imitation Game.Jurnal EKomunikasi Vol. 4. No.1.Surabaya: Universitas Kristen Petra.

Berlan, E. D (2010). Sexual Orientation and Bullying among adolesescent in the Growing up Today Study. Journal of Adolescent Health: Vol: 46: 366-371.

Borg, I \& Elizur, D (1992). Job Insecurity: Correlates, Moderator, and Measurement. International.Journal of Manpower. Vol 13. No. 2: 13-26.

Brouwer, M.A.W (1982). Kepribadian dan Perubahannya. Jakarta: PT. Gramedia.

Clark, Moustakas (1994). Phenomenological Research Methods. California: SAGE.

Colin, Spencer (2004). Sejarah Homoseksualitas. Yogyakarta: Kreasi Wacana.

Corytawat, Nova \& Lobodally, Altobeli. (2018). Komunikasi Verbal Dan Nonverbal Di Antara Kaum Homoseksual. Jurnal Cakrawala. ISSN 16936248.

Deddy, Mulyana (2001). Ilmu Komunikasi: Suatu Pengantar. Bandung: PT. Remaja Rosdakarya

Deddy, Mulyana (2004). Ilmu Komunikasi Suatu Pengantar. Bandung: PT. Remaja Rosdakarya.

Ellis, D (1993). Modelling the Information-Seeking Patterns of Academic Researcher: A Grounded Theory Approach. Library Quarterly.

Henefer, Jean ( 2005). Krikelas's Model Of Information Seeking. Ireland: University of Dublin.

Julia T.Wood. 2005. Gendered Lives: Communication, Gender \& Culture. America: Wadsworth Engage Learning.

Kamus Besar Bahasa Indonesia Edisi Kedua.

Lestari, S (2012). Psikologi Keluarga: Penanaman Nilai dan Penanganan Konflik dalam Keluarga. Jakarta: Kencana Prenada Media Group.

Levay, Simon (1996). Queer Science: The Use and Abuse of Research into Homosexuality. Cambridge: The MIT Press.

Moustakas, Clark. 1994. Phenomenological Research Methods. New Delhi: Sage Publication. 
Musti'ah (2016). Lesbian Gay Bisexual and Transgender (LGBT): Pandangan Islam, Faktor Penyebab, dan Solusinya.Jurnal Pendidikan Sosial. Vol 3. No. $2:$ 258-273.

Oetomo, Budi Stedjo Dharma (2002). Perencanaan dan Pengembangan Sistem Informasi. Edisi 1. Yogyakarta: ANDIPeriantalo, J. (2016). Penelitian Kuantitatif Untuk Psikologi. Yogyakarta : Pustaka Pelajar.

Philips, A. A. \& Khan, Z (2003). Islam dan Homoseksual. Jakarta: Pustaka Zahra.

Siahaan, Jokie M.S9 (2009). Perilaku Menyimpang: Pendekatan Sosiologis. Jakarta: PT. Indeks.

Suherry (2016). Lesbian, Gay, Biseksual, dan Transgender (LGBT) dalam Perspektif Masyarakat dan Agama.Jurnal Aristo, Vol.4. No. 2: 89-99.

Suryana (2010). Metode Penelitian Model Praktis Penelitian Kuantitatif dan Kualitatif. Bandung: UPI.

Syah, Djalinus dkk (1993). Kamus Pelajar. Jakarta: Rieneka Cipta. 